\title{
EXTENSIVE PREDATOR PERSECUTION CAUSED BY POPULATION CRASH IN A GAME SPECIES: THE CASE OF RED KITES AND RABBITS IN SPAIN
}

\author{
Rafael Villafuerte, ${ }^{a *}$ Javier Viñuela $^{b} \&$ Juan Carlos Blanco ${ }^{c}$ \\ ${ }^{a}$ Estación Biológica de Doñana (CSIC), Apdo. 1056, 41080 Sevilla, Spain \\ ${ }^{b}$ Sociedad Española de Ornitologia, Carretera de Húmera 63-1, 28024 Pozuelo, Madrid, Spain \\ 'Departamento de Geografía, Urbanismo y Ordenación del Territorio, Universidad de Cantabria, Avda. de los Castros, \\ $s / n 39005$ Santander, Spain
}

(Received 24 September 1996; accepted 5 June 1997)

\begin{abstract}
The European rabbit Oryctolagus cuniculus, an important game species in Spain, has declined sharply since the arrival of haemorrhagic disease in 1988. As a consequence of this decline, it appears that illegal and extensive persecution of predators has increased. We have assessed the impact of this persecution on red kites Milvus milvus. Around $90 \%$ of the populations studied have declined during the last 3-10 years, and the species' range has been reduced since 1980, particularly in high rabbit density areas (those most valuable for hunters). Currently, stable or increasing populations of red kites are located in areas of low rabbit density. Their abundance in areas of high rabbit density is similar to that recorded during the 1970s, when, after the spread of myxomatosis over Spain, government-sponsored campaigns of vermin extermination were carried out. Although red kites cannot be considered important predators of rabbits, they are disproportionally suffering the effects of human persecution, because of their susceptibility to shooting and poisoning, and a lack of understanding among hunters. We discuss the management strategies that might be used during population crashes of game species to avoid unjustified persecution of predators. (C) 1998 Elsevier Science Ltd. All rights reserved.
\end{abstract}

Keywords: illegal persecution, Oryctolagus cuniculus, Milvus milvus, rabbit haemorrhagic disease, Spain.

\section{INTRODUCTION}

Persecution of predators to prevent real or perceived damage to game species is a frequent cause of their decline or extinction (Bijleveld, 1974; Newmark, 1987; Reynolds and Tapper, 1996). Although the increasing concern for nature conservation has reduced the traditional negative perception of predators (Kellert, 1985),

*To whom correspondence should be addressed. they are usually blamed whenever human hunting success decreases for whatever reason, and the hunting lobby then demands predator control (Franzmann, 1993). When management agencies do not respond to their requests, confrontations may arise, and an increase of illegal persecutions can be expected.

European rabbits Oryctolagus cuniculus are the keystone species in the Iberian vertebrate ecosystem (Valverde, 1967), being a staple prey for at least 29 species of predators (Delibes and Hiraldo, 1981). Rabbits are also one of the main game species in Spain, where hunting is a very important economic activity $(>1$ million hunters were estimated to have generated at least $\$ 1.2 \times 10^{9}$ annually; J. Delibes, pers. comm.).

Simultaneously with the outbreak of myxomatosis in Spain during the 1950s, the government-sponsored council for vermin extinction (Junta de Extinción de Alimañas) was responsible for a drastic reduction in predators, e.g. almost 10000 kites (red kites Milvus milvus plus black kites $M$. migrans) killed between 1954 and 1961 (Garzón, 1974). Although rabbit populations remained low for some time after myxomatosis, they probably began to increase in the 1970s (Lloyd, 1981). Legal persecution of predators ended in 1973, and the Spanish government began a strategy of conservation of predators similar to that in other western European countries (Bijleveld, 1974; Garzón, 1977). As a consequence, many threatened predators recovered: wolf Canis lupus populations increased notably due to the ban on poison baits (Blanco et al., 1992); populations of Spanish imperial eagle Aquila adalberti, black vulture Aegypius monachus, and bearded vulture Gypaetus barbatus, increased 3-7 fold (Heredia, 1991; González, 1989, 1996); griffon vulture Gyps fulvus experienced such a large increase that they are currently considered 'Non-threatened' (Blanco and González, 1992).

Rabbit haemorrhagic disease (RHD) reduced rabbit populations between one-half and two-thirds between 1988 and 1993 (Villafuerte et al., 1994, 1995). This is 
probably the reason why, between 1990 and 1993, hunting licences decreased by $c$. $10 \%$, after having increased for $>20$ consecutive years (Ministerio de Agricultura Pesca y Alimentación; M.A.P.A., 1993). Although hunters increased their demands for predator control, almost no efforts have been made by regional agencies, probably because of the lack of information on the effects of predators on game species.

In Spain, there are more than 30000 private hunting areas that cover $>70 \%$ of the country (M.A.P.A., 1993). Many of these areas are fenced and have gamekeepers, and, thus, state wardens restrict surveillance mainly to public areas. Many of the present land owners and gamekeepers are still those that legally reduced predator populations up until 1973. Consequently, a decline in rabbits could easily lead to an increase in illegal persecution of predators (Bijleveld, 1974; De Juana, 1989; Reynolds and Tapper, 1996).

The red kite may serve as a good indicator for assessing the effects of shifts in persecution practices on predator populations in Spain. This relatively abundant species is especially vulnerable to poisoning campaigns, nest robbing and shooting, given that it is a gregarious carrion-eater and opportunistic searcher (Cramp and Simmons, 1980; Lovegrove et al., 1990; Spierenburg et al., 1990; Evans and Pienkowski, 1991), and it is commonly associated with towns, roads, and rubbish dumps (Lovegrove et al. 1990; Cortone et al., 1994; Voisin, 1994; Viñuela, 1996). Red kites prey upon rabbits whenever they are abundant and accessible (e.g. Veiga and Hiraldo, 1990), and consequently, unless other factors are acting, we should expect a high density of red kites in areas where rabbits are abundant, as occurs in the case of the black kite (Viñuela et al., 1994).

Our general objective was to evaluate the relationship between changes in abundance and the range of red kites during the last few years and hunting in different regions of Spain. By assuming that the hunting value of an area is proportional to rabbit abundance, we also investigated the possible relationship between some features of hunting areas and rabbit abundance. We expected that illegal control of predators would be more intense in those areas with lower surveillance by government wardens. Finally, we also hypothesized that illegal persecution would be higher in areas with higher hunting value.

\section{METHODS}

\section{Red kite surveys}

Data on range and population density of nesting red kites were extracted from the National Census carried out during the breeding season of 1994 (Viñuela, 1994, in press). All the distribution area described by Cramp and Simmons (1980) was surveyed, using the U.T.M grid of $10 \times 10 \mathrm{~km}$ as the sampling unit. The study area was stratified following habitat and topographic criteria, and the census was conducted by $>500$ volunteer observers and regional ornithologists. Every stratum was sampled completely when possible, but if there were insufficient observers, a random sample of squares was selected to cover a minimum of $50 \%$ of the area of each stratum.

In a sample of $6110 \times 10 \mathrm{~km}$ squares, red kite populations were surveyed simultaneously by road transects and nest searching/detection of territorial pairs (Craighead and Craighead, 1956). We calculated an index of relative density (IRD, no. of kites $/ 100 \mathrm{~km}$ of transect; Ferry and Frochot, 1958) for each square sampled. A linear regression of IRDs on estimated populations for the sampled squares explained $>85 \%$ of the variance in IRDs (Viñuela, 1997). This equation was used to estimate the populations within each square sampled in the national census. High density areas for red kites were considered to be those with IRDs $>10$ (estimated population $>3$ pairs/square) or, for the squares sampled by nest searching/detection of pairs, those with $>3$ nesting pairs. Additional details are given elsewhere (Viñuela, 1994, 1997, in press).

We also sought the views of ornithologists regarding trends in red kites during the last 3-10 years. Surveys during consecutive years (1992-1994) were made in some study areas, to assess possible changes in population size (Table 1). We have included only those reports in which the population changes were clearly confirmed, owing to the existence of surveys in consecutive years or to evident and large changes in population size. We also requested information about known cases of poisoning or shooting.

We compared IRDs of breeding red kites obtained by Meyburg (1973) during the 1970s, when raptor populations had been decimated after many years of systematic legal persecution, with those obtained during the spring of 1994. Data were available for five areas (Southwest Pyrenees, Salamanca, Avila, Extremadura and Toledo, see Fig. 1).

\section{Rabbit surveys}

We used 1:100,000 maps (Army cartography service) to carry out a $4 \mathrm{~km}$ walking transect for systematic sampling of rabbit abundance. A total of 311 transects were completed during June and July 1993 (Blanco and Villafuerte, 1993; Villafuerte et al., 1995). On each transect, observers recorded number of rabbit excrements, rabbits observed, foraging scrapes, and warren entrances. Using these variables, we carried out a principal component analysis to generate a new variable (RA) to provide the best overall measure of abundance. The RA values were plotted on a map and lines with equal values were drawn using commercial software (SURFER, Golden Software Inc.). In each survey were noted the type of land (private or public), presence/absence of fences, and the abundance of carnivores by counting all the scats found along the transect. Because hunting pressure in Spain has not been accurately determined 
Table 1. Population trends of red kites in several local populations during 1984-1994, and rabbit abundance (RA)(x100) in the same areas (see Fig. 1)

\begin{tabular}{|c|c|c|}
\hline Study area & Population trend & RA \\
\hline Asturias (1) & Apparently extinct & $23 \cdot 3$ \\
\hline Galicia (2) & Almost extinct & 7.2 \\
\hline Sanabria (3) & Apparently extinct & $6 \cdot 8$ \\
\hline León (4) & Strong decline $(>50 \%)$ & 3.7 \\
\hline Alava-North Burgos (5) & Decline & 7.8 \\
\hline Navarra (6) & Stable or increase & 31 \\
\hline Zaragoza (7) & Increase $(>100 \%)$ & 1 \\
\hline NW Huesca (8) & Increase $(>100 \%)$ & 1 \\
\hline Valladolid (9) & Decline & $83 \cdot 3$ \\
\hline Aranda de Duero (10) & Apparently extinct & 5.5 \\
\hline Duratón (11) & Strong decline $(70 \%)$ & $45 \cdot 3$ \\
\hline Rio Moros (12) & Strong decline $(>50 \%)$ & 3.8 \\
\hline SW Salamanca (13) & Decline & 7.9 \\
\hline Béjar-Guijuelo (14) & Decline & $9 \cdot 6$ \\
\hline El Tiemblo (15) & Strong decline $(>50 \%)$ & 0.8 \\
\hline Madrid (16) & Strong decline $(40-100 \%)$ & 73.9 \\
\hline South Avila (17) & Strong decline $(40-80 \%)$ & 15.4 \\
\hline Navas del Marqués (18) & Decline $(>30 \%)$ & $786 \cdot 2$ \\
\hline Hervás (19) & Decline & $32 \cdot 5$ \\
\hline Central Cáceres (20) & Stable & 79.9 \\
\hline Tietar Valley (21) & Strong decline $(>40 \%)$ & 45.4 \\
\hline Toledo Mounts (22) & Apparently extinct & $2 \cdot 2$ \\
\hline Alcudia valley (23) & Strong decline & 65.4 \\
\hline SE Ciudad Real (24) & Extinct & 367 \\
\hline Córdoba (25) & Apparently extinct & 451 \\
\hline Jaén-Granada (26) & Almost extinct & 430 \\
\hline SW Albacete (27) & Apparently extinct & 2 \\
\hline W Andalucía (28) & Strong decline $(>40 \%)$ & $32 \cdot 1$ \\
\hline Doñana (29) & Slight decline $(10-20 \%)$ & 178 \\
\hline
\end{tabular}

Sources $^{a}$ : (1) C. M. Alvárez, L. M. Arce; (2) A. Villarino; (3) T. Rivero, H. Hernández, own data; (4) A. Onrubia, I. Sim, own data; (5) A. F. Rodríguez, G. Artiguez; (6) A. Senosiaín, Elósegui (1985), J. I. Deán, 1994 census; (7) F. Compaired; (8) Kostrzewa et al. 1986, 1994 census; (9) J. Fernández, A. Balmori; (10) AFFA; (11) V. Garza; (12) own data; (13) J. Martín; (14) L. Bejarano, J. Gómez-Labrador; (15) J. L. Robledo, own data; (16) E. Soto-Largo, C. Sunyer, A. Rodríguez, J. A. Diaz, own data; (17) Sansegundo (1987), 1994 census, own data; (18) C. Jarque, own data; (19) J. Sánchez; (20) P. Mateo, P. Fernández, I. Sim, own data; (21) A. Acha, L. S. Cano, own data; (22) M. López, own data; (23) R. Palomo; (24) T. Gullick; (25) Torres et al. (1981), F. Cabello, J. Bustamante; (26) J. Muñoz, J. M. Gil; (27) J. Escudero; (28) F. J. Avila, F. Hiraldo, M. C. Pérez; (29) F. Hiraldo, own data.

${ }^{a}$ Personal communications except where dates refer to published sources.

and is only available on a provincial scale (M.A.P.A., 1993), we considered also the number of cartridge cases found along the survey as an index of hunting pressure.

\section{RESULTS}

\section{Red kite range and trends}

The range of red kite has been reduced in recent years, and is currently less than half that described by Cramp and Simmons (1980) during the 1970s (Fig. 1). This reduction has been especially noticeable during the last 3-10 years, affecting 25 of the 29 populations for which we have estimates (Fig. 1, Table 1). In all these areas, direct persecution through poisoning or shooting has been claimed by local ornithologists as the main reason for the declines.

We compiled 91 confirmed cases of red kites dead from human persecution, 77 of which were from poisoning. Three other cases involving a high but undeter- mined number of poisoned red kites have also been reported.

\section{Present rabbit abundance}

Rabbits occur throughout Spain, except in the higher ranges of the Pyrenees (Flux, 1994). However, there is great variation in population densities as expressed by our abundance index (RA mean $0.54, \mathrm{SE}=0.06$, range $0-7.87)$. High densities of rabbits are found in central and southern Spain, while the rest of the country may be considered a low density area (Fig. 2). According to these results, the average value of RA per province was correlated ( $r=0.446, n=47, p=0.002)$ with the number of rabbits killed per $\mathrm{km}^{2}$ in each province during 1993 (M.A.P.A., 1993).

\section{Relationships between red kites and rabbits}

Red kite populations located within high density rabbit areas have either disappeared (Nos 20 and 23 in Fig. 1), or suffered alarming declines (e.g. Nos 9, 10 13, 14, 15, 


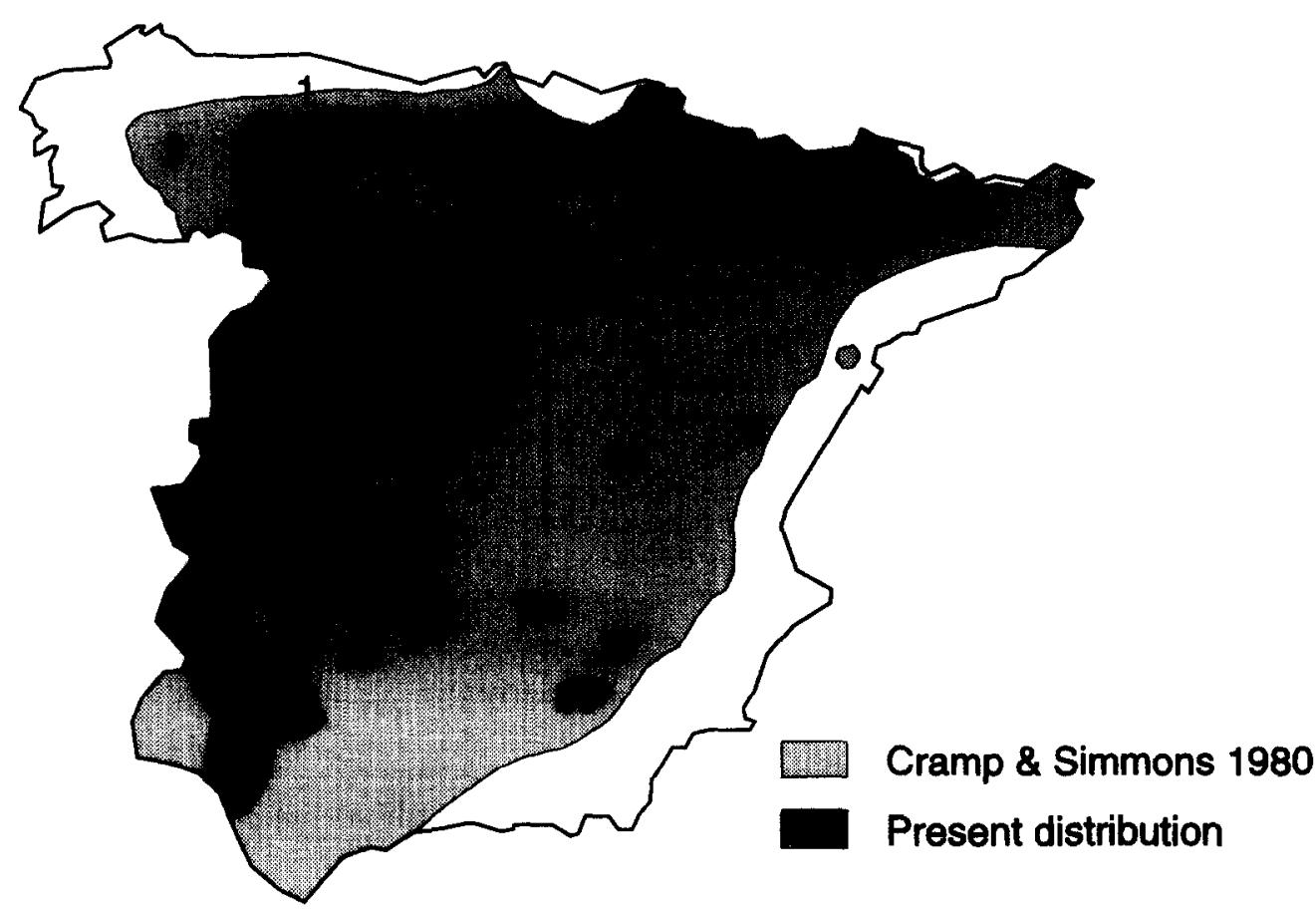

Fig. 1. Past (Cramp and Simmons, 1980) and current (National Census of 1994) distribution of red kites in Spain. Numbers indicate location of local populations for which recent information on population trends is available (population declines in all except numbers 5, 6 and 18, see Table 2). Question marks indicate localities where the species may still breed, but unconfirmed during the census. Letters and numbers are areas referred to in the text and Tables (A, Avila; E, Extremadura; S, Salamanca; SWP, Southwest Pyrenees; T, Toledo).

19, 21 in Fig. 1). Most of these populations are in a very precarious situation, being represented by isolated pairs or small numbers. Most of the secure populations are located in areas of low rabbit density (Fig. 2), though even here, some populations are also suffering severe decline (Nos 1, 2 and 4, Fig. 1). Grouping the red kite populations trends in three categories (extinct or almost extinct, sharp decline, and stable or increasing; see Table 1), we found a marginally significant difference in RA between categories (Kruskal-Wallis statistic $=5.64$; $p=0.060$; RA means: $0.69,1.31,0.20$, respectively).

The comparison between the abundance indices obtained during this study with those presented by Meyburg (1973) during the 1970s, indicate that red kite populations have actually increased in areas of low rabbit density (SW Pyrenees and Salamanca, Table 2

Table 2. Comparasion between the IRDs (index of relative density, No. of kites $/ 100 \mathrm{~km}$ ) obtained from road transect surveys by Meyburg (1973) during the 1970s with those obtained during spring-summer 1994 in the same ares of Spain (see Fig. 1).

\begin{tabular}{lcr}
\hline Study area & \multicolumn{2}{c}{ Number of red kites $/ 100 \mathrm{~km}$} \\
\cline { 2 - 3 } & Meyburg (1973) & 1994 \\
\hline Southwest Pyrenees & 3.6 & 20.1 \\
Salamanca & 8.3 & 22.6 \\
Avila & 5.6 & 5.5 \\
Extremadura & 0.7 & 10.7 \\
Toledo & 1.1 & 1.5 \\
\hline
\end{tabular}

and Fig. 1). Similar abundance indices were found in two areas with high density of rabbits, where some of the most significant declines in red kite populations have been recorded (Toledo and Avila, Table 1 and Fig. 1). The only area with high rabbit density where red kites seem to be much more abundant now than 20 years ago is Extremadura.

\section{Abundance of rabbits, type of property and hunting pressure}

Indices of rabbit abundance obtained on private hunting lands $(0.65 \pm 0.07, n=203)$ were higher than those obtained on public lands $(0.33 \pm 0.09, n=108$; ANOVA, $F_{1,309}=7.268, p \leq 0.01$ ). Also, rabbit abundance was higher on hunting lands with restricted access $(1.22 \pm 0.14, n=47)$, than on lands without restrictions $\left(0.41 \pm 0.06, n=264 ; F_{1,309}=28.204, p \leq 0.001\right)$. Hunting pressure (cartridges $/ \mathrm{km}$ ) was also higher on private lands $(19.4 \pm 2 \cdot 5, n=203)$ than on public lands $(8.25 \pm$ 3.4; ANOVA, $F_{1,309}=7.01, p=0.008$ ). There were significant correlations between rabbit abundance and hunting pressure $(r=0.478, p<0.001, n=311)$, and between hunting pressure and the number of carnivore scats $(r=0.124, p=0.029, n=311)$. There was no correlation between the RA and the abundance of carnivores when all kinds of properties were pooled $(r=-0.0001$, $p=0.998$ ). However, we found a correlation between carnivore numbers and rabbit abundance on public lands $(r=0.257, p=0.007, n=108)$, but not on private lands $(r=-0.053, p=0.452, n=203)$. 


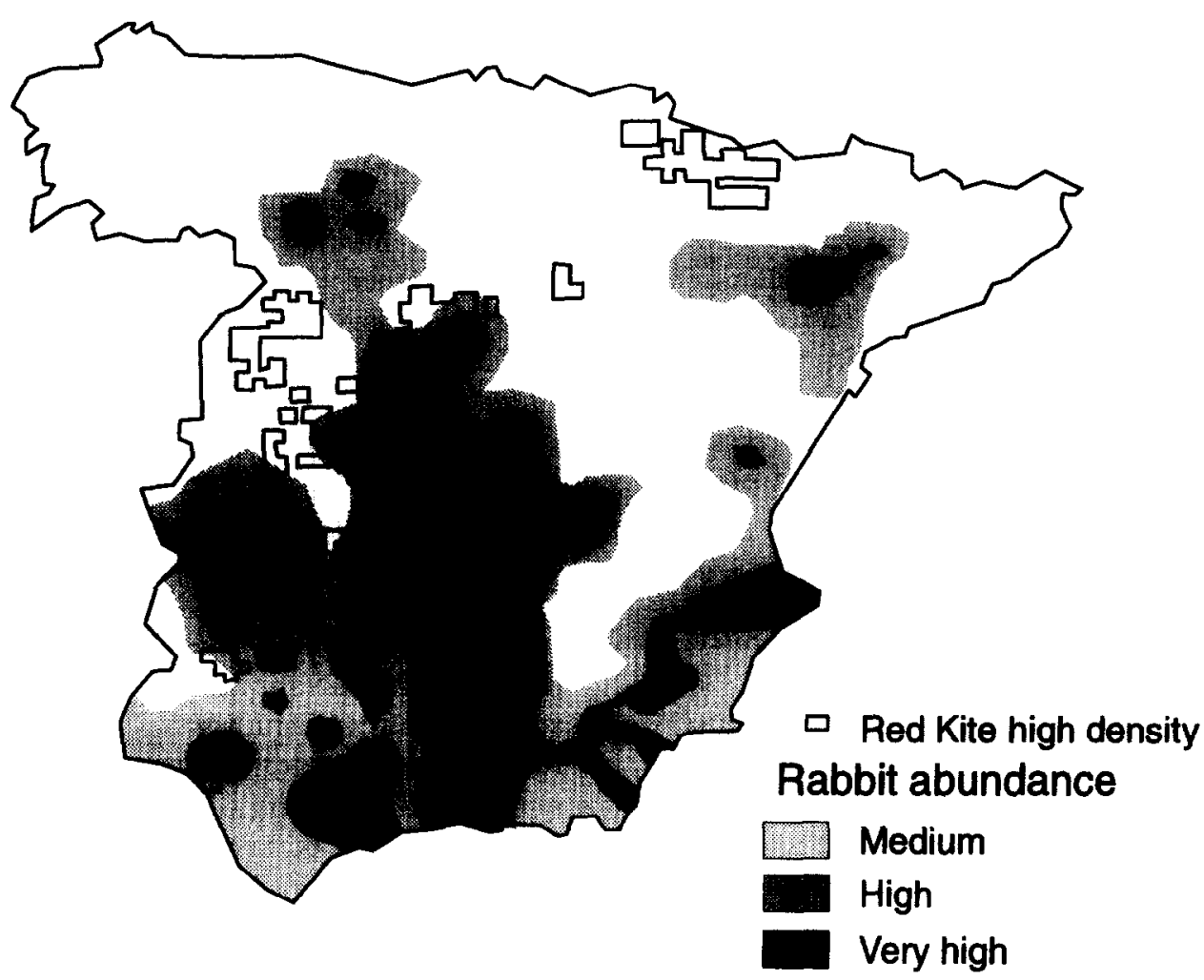

Fig. 2. Areas of high density of red kites ( $>10 \mathrm{kites} / 100 \mathrm{~km}$ of transect, estimated population $>3$ pairs $/ 100 \mathrm{~km}^{2}$; data from National Census of 1994), and density distribution of rabbits (abundance indexes higher than the average for the country) in Spain. The rest of the country is considered to have lower than average rabbit density.

\section{DISCUSSION}

Red kite populations experienced dramatic declines during the 19th century and first half of this century, mainly due to persecution (Bijleveld, 1974; Evans and Pienkowsky, 1992). Their populations in Central Europe have recovered in recent decades (Tucker and Heath, 1994), but declines still persist in the Mediterranean basin, also mainly due to persecution (Viñuela, 1996). Currently, in Spain, they are very scarce within areas of high rabbit density, but this is probably not related to the decline of rabbits (see below). Only those populations of red kite outside high rabbit density areas have experienced stability or an increase.

The current rabbit range is not very different to that before irruption of myxomatosis, because climatic conditions (e.g. rain and temperature) and/or soil structure (i.e. suitability for warren building) are two of the most important factors affecting rabbit distribution (Blanco and Villafuerte, 1993). Furthermore, because of their economic importance, most of those areas where rabbits were specially abundant in the past have being maintained as hunting areas up to the present, even by restocking with rabbits from other areas (Calvete et al., 1997).

Generalist predators may be affected by RHD, through reduction in litter size (Villafuerte et al., 1996), or productivity (Fernández, 1993). However, the appearance of dead or ill rabbits affected by RHD may even have been favourable for kites, because they gain access to adult rabbits, an otherwise unavailable prey (Viñuela and Veiga, 1992; Villafuerte and Viñuela, unpublished data). In fact, the highest productivity of breeding red kites in Britain between 1951 and 1960 was 1954, when myxomatosis spread (Lovegrove et al., 1990). Furthermore, even in a high rabbit density area, such as Donana National Park, the percentage of rabbits in the diet of red kites before the irruption of RHD was relatively low (Veiga and Hiraldo, 1990). More importantly, many population declines have occurred in too short a time period (in many cases $2-3$ years, pers. obs.), to be explained by a reduction in productivity.

An alternative hypothesis to explain this reduction could be competition with other raptors more specialized in rabbit consumption, so there could be a case of control by top predators (Palomares et al., 1995; but see Litvaitis and Villafuerte, 1996). However, in Doñana (No. 25 in Fig. 1), where rabbits are very abundant (Moreno and Villafuerte, 1995), a dense population of red kites coexists with one of the most diverse communities of raptors in Europe (Valverde, 1967; Veiga and Hiraldo, 1990; pers. obs.), including a dense population of the Spanish imperial eagle, which occasionally kills kites (Ferrer, 1993)

Red kites are probably being affected also by other human impacts, such as the increase in the number of electric power lines, use of pesticides, destruction of nesting habitat, or a decline in abundance or accessibility to rubbish tips and abattoirs (Viñuela, 1994, 1996, in press). However, these factors are more closely related 
to settled areas than to hunting areas, and cannot explain the striking relationship between rabbit and red kite abundance.

Blanco and Villafuerte (1993) found that many hunters believed that predators were the main cause of the decrease in rabbit numbers, and some even admitted the use of illegal methods to kill predators. Accordingly, we found that there was no correlation between rabbit densities and carnivore abundance on private hunting lands, in contrast to public hunting lands, albeit the former held the largest numbers of rabbits, a result difficult to explain by reasons other than illegal persecution.

Furthermore, there is a general impression among hunters that there are 'too many kites' in Spain. This is because large numbers of kites are present throughout the year: around 60000 wintering red kites (OctoberFebruary, Viñuela, 1997, in press), and at least 10000 pairs of breeding black kites (February-August, Viñuela and Sunyer, 1994). Unfortunately, the lower number of resident nesting red kites (about 3500 pairs, Viñuela, 1997 , in press) seem to be suffering disproportionally the effects of persecution.

Spain may be experiencing a situation resembling that which occurred during the myxomatosis crash, when the vermin extermination campaigns reduced the numbers of predators. In fact, we found that in areas of high rabbit density the present abundance indices for red kites are similar to those found during the vermin campaigns, while in areas of low rabbit density, the populations of red kites seem to be much higher now than before (Table 2).

Other recent studies have reported an increase in the number of cases of poisoned or shot raptors in Spain (e.g. Blanco, 1995; González, 1996). Indirect poisoning (B. Artiguez and A. F. Rodriguez, pers. comm.) seems also to be playing an important role in northern Spain (numbers 1, 2, 4 in Fig. 1), outside the high rabbit abundance area, where bait is being used against wolves (Blanco et al., 1992), because of conflicts with livestock producers.

In Extremadura, an area of high density of rabbits, populations of red kites are apparently stable (Table 1), and much higher than in the times of vermin extermination (Table 2). A controlled persecution of generalist carnivores is allowed in some areas of this region, and illegal persecution is severely penalized (A. Sánchez, Environmental Agency of Extremadura, pers. comm.). Other undetected factors may also contribute to the good health of the kite population in Extremadura.

In Scottish estates, shooting and nest destruction are the most important factors reducing nesting populations of hen harriers Circus cyaneus (Bibby and Etheridge, 1993). Gamekeepers, concerned over the increase in hen harrier numbers and their possible effect on grouse populations (Redpath, 1991), are responsible for this persecution. As in the case of red kites in Spain, the only dense populations of hen harriers in Scotland are cur- rently those outside shooting estates (Bibby and Etheridge, 1993).

In Spain, the effect of predators on game species is currently unclear, although gamekeepers and hunters seem to be convinced of their influence. When a decrease in hunting success is perceived, predators are usually blamed (Franzmann, 1993), and hunters may start to use illegal, but easy, fast, and cheap methods of predator control, such as poison, that could affect 'nonguilty' but vulnerable species, such as red kites. In Britain, Reynolds and Tapper (1996) explained the lower number of illegal practices against carnivores when compared with raptors, because of the existence of 'efficient and satisfactory' legal methods to control targeted mammalian predators.

It is always better to accept a regulated and monitored control of predators than uncontrolled illegal actions. However, studies to gather information on the real effect of predators on game population are urgently required. If necessary, a reliable methodology should then be found to compensate for the effect of predators.

Finally, and more importantly, information campaigns at the very early stage of a population crash in a game species can prevent misconceptions that will be very difficult to erradicate in the future. This will allow conservationists and wildlife managers to take the initiative in preventing extensive predator persecution, especially for the most endangered and sensitive species.

\section{ACKNOWLEDGEMENTS}

The national rabbit survey was funded by the Spanish Nature Conservation Agency (ICONA). This is a contribution to the project 'Status of the red kite in Spain' financed by the Royal Society for the Protection of Birds (RSPB) and coordinated by the Spanish Ornithological Society (SEO). We acknowledge the contribution of more than 500 volunteers who made possible the census in such a large area. We thank John A. Litvaitis, Steven R. Beissinger, Gloria Jordán, Sacramento Moreno, and Douglas F. Smith for helpful comments on previous drafts. During the last stages of analysis and writing RV was supported by a MEC post-doc Fellowship and the project PB 94-0480 and, JV was supported by a Fullbright Post-doc Fellowship, and JCB was sponsored by ATECMA.

\section{REFERENCES}

Bibby, C. J. and Etheridge, B. (1993) Status of the Hen Harrier Circus cyaneus in Scotland in 1988-1989. Bird Study 40, 1-11.

Bijleveld, M. (1974) Birds of Prey in Europe. MacMillan Press, London, UK

Blanco, J. C. (1995) La función de la predación en los ecosistemas naturales. In Predación, caza y vida silvestre, pp. 1119. Fundación La Caixa. Ed. Aedos, Madrid. 
Blanco, J. C. and González, J. L. (1992) El libro rojo de los vertebrados de España. ICONA, Colección Técnica, Madrid.

Blanco, J. C. and Villafuerte, R. (1993) Factores ecológicos que influyen sobre las poblaciones de conejos. Incidencia de la enfermedad hemorrágica. ICONA, Internal report.

Blanco, J. C., Reig, S. and Cuesta, L. (1992) Distribution, status and conservation problems of the wolf Canis lupus in Spain. Biol. Conserv. 60, 73-80.

Calvete, C., Villafuerte, R., Lucientes, J. and Osácar, J. J. (1997) Effectiveness of traditional wild rabbit restocking in Spain. J. Zool. 241, 271-277.

Cortone, P., Minganti, A., Pellegrini, M., Riga, F., Sigismondi, A. and Zocchi, A. (1994) Population trends of the Red Kite Milvus milvus in Italy. In Raptor Conservation Today, ed. B.-U. Meyburg and R. D. Chancellor, pp. 29-32. Proc. of the IV World Conference on Birds of Prey and Owls, Berlin, 1992.

Craighead, J. J. and Craighead, F. C. Jr. (1956) Hawks, Owls and Wildife. Stackpole, Washington D.C, USA.

Cramp, S. and Simmons, K. E. L. (1980) The Birds of the Western Palearctic, Vol. II. Oxford University Press, Oxford, UK.

De Juana, F. (1989) Situación actual de las rapaces diurnas (O. Falconiformes) en España. Ecologia 3, 237-292.

Delibes, M. and Hiraldo, F. (1981) The rabbit as prey in the Iberian Mediterranean ecosystem. In Proceedings of the I World Lagomorph Conference, ed. K. Myers, and C. D. MacInnes, pp. 614-622. Guelph, Canada.

Elósegui, J. (1985) Atlas de las aves nidificantes en Navarra. Caja de Ahorros de Navarra, Pamplona, Spain.

Evans, I. and Pienkowski, M. W. (1991) World status of the red kite. A background to the experimental reintroduction to England and Scotland. British Birds 84, 171187.

Fernández, C. (1993) Effect of the viral haemorrhagic pneumonia of the wild rabbit on the diet and breeding success of the golden eagle Aquila chrysaëtos (L.). Rev. Ecol. Terre Vie 48, 323-329.

Ferrer, M. (1993) El aguila imperial. Quercus, Madrid.

Ferry, C. and Frochot, B. (1958) Une methode pour denombrer les oiseaux nichcurs. La Terre et la Vie 12, 85102.

Flux, E. C. (1994) World distribution. In The European Rabbit. The History and Biology of a Successful Colonizer, ed. H. V. Thompson and C. M. King, pp. 8-21. Oxford University Press, Oxford, New York, Tokyo.

Franzmann, A. W. (1993) Biopolitics of wolf management in Alaska. Alces 29, 9-26.

Garzón, J. (1974) Contribución al estudio del estatus, alimentación y protección de las Falconiformes en España Central. Ardeola 19, 279-330.

Garzón, J. (1977) Birds of prey in Spain: their present situation. In Proceedings of the I World Conference of Birds of Prey, ed. R. D. Chancellor, pp. 159-170. ICBP, Cambridge, UK.

González, L. M. (1989) Resultados preliminares del censo nacional de buitre negro en España. ICONA, Madrid.

González, L. M. (1996) Situación actual del Aguila Imperial Ibérica en el Mediterráneo. In Biología y conservación de las Rapaces Mediterráneas, ed. J. Muntaner and $\mathbf{J}$. Mayol, pp. 61-76. Actas del VI Congreso de Biología y Conservación de las Rapaces Mediterráneas, Palma de Mallorca, Spain.

Heredia, R. (1991) Distribución y status poblacional en España. In El quebrantahuesos (Gypaetus barbatus) en los Pirineos, ed. R. Heredia and B. Heredia, pp. 15-23. ICONA, Colección Técnica, Madrid.

Kellert, S. R. (1985) Public perceptions of predators, particularly the wolf and the coyote. Biol. Conserv. 31, 167-189.
Kostrzewa, A., Ferrer-Lerin, F. and Kostrzewa, R. (1986) Abundance, status and vulnerability of raptors and owls in parts of the Spanish Pyrenees. Birds of Prey 3, 182-190.

Litvaitis, J. A. and Villafuerte, R. (1996) Intraguild predation, mesopredator release, and prey stability. Conserv. Biol. 10, 676-677.

Lloyd, H. G. (1981) Biological observations on postmyxomatosis wild rabbit populations in Britain, 1955-1979. In Proceedings of the I World Lagomorph Conference, ed. $\mathrm{K}$. Myers and C. D. MacInnes, pp. 623-628. Guelph, Canada.

Lovegrove, R., Elliott, G. and Smith, K. (1990) The Red Kites in Britain. RSPB Conservation Review, Sandy, UK.

Ministerio de Agricultura Pesca y Alimentación. (1993) Anuario de estadisticas agrarias de 1993

Meyburg, B. U. (1973) Observations sur l'abondance relative des rapaces (Falconiformes) dans le nord et l'ouest de l'Espagne. Ardeola 19, 129-140.

Moreno, S. and Villafuerte, R. (1995) Traditional managements of scrublands for the conservation of rabbits Oryctolagus cuniculus and their predators in Donana National Park, Spain. Biol. Conserv. 73, 81-85.

Newmark, W. D. (1987) A land-bridge island perspective on mammalian extinctions in western North American parks. Nature 325, 430-432.

Palomares, F., Gaona, P., Ferreras, P. and Delibes, M. (1995) Positive effects on game species of top predators by controlling smaller predator populations: an example with lynx, mongooses, and rabbits. Conserv. Biol. 9, 295-305.

Redpath, S. M. (1991) The impact of Hen Harriers on Red grouse breeding success. J. App. Ecol. 28, 659-671.

Reynolds, J. C. and Tapper, S. C. (1996) Control of mammalian predators in game management and conservation. Mammal Rev. 26, 127-156.

Sansegundo, C. (1987) Atlas de las aves nidificantes de la provincia de Avila. Ph.D. thesis, Universidad Complutense de Madrid.

Spierenburg, T. J., Zoun, P. and Smit, T. (1990). Poisoning of wild birds by pesticides. Wild birds mortality in the Netherlands 1975-1989. Working group on Wild Birds Mortality, N.S.P.B.

Torres, J. A., Jordano, P. and León, A. (1981) Aves de presa diurnas de la provincia de Córdoba. Publicaciones M. P. y C. A., Córdoba, Spain.

Tucker, G. M. and Heath, M. F. (1994) Birds in Europe: their conservation status. Birdlife Conservation Series no. 3 Birdlife, Cambridge, UK.

Valverde, J. A. (1967) Estructura de una comunidad de Vertebrados terrestres. Monografías de la Estación Biológica de Doñana, 1. CSIC, Madrid, Spain.

Veiga, J. P. and Hiraldo, F. (1990) Food habits and the survival and growth of nestlings in two simpatric kites (Milvus milvus and Milvus migrans). Hol. Ecol. 13, 62-71.

Villafuerte, R., Calvete, C., Gortázar, C. and Moreno, S. (1994) First epizootic of rabbit haemorrhagic disease in free living populations of Oryctolagus cuniculus at Donana National Park, Spain. J. Wildl. Dis. 30, 176-179.

Villafuerte, R., Calvete, C., Blanco, J. C. and Lucientes, J. (1995) Incidence of viral haemorrhagicic disease in wild rabbits populations in Spain. Mammalia 59, 651-659.

Villafuerte, R., Luco, D. F., Gortázar, C. and Blanco, J. C. (1996) Effect on red fox litter size and diet after rabbit haemorrhagic disease in north-eastern Spain. J. Zool. 240, 764 767.

Viñuela, J. (1994) Status of the red kite in Spain. Summer season. RSPB Research reports, Sandy, UK.

Viñuela, J. (1996) Situación del Milano Real (Milvus milvus) en el Mediterráneo. In Biología y conservación de las Rapaces Mediterráneas, ed. J. Muntaner and J. Mayol, pp. 91- 
100. Actas del VI Congreso de Biología y Conservación de las Rapaces Mediterráneas, Palma de Mallorca, Spain.

Viñuela, J. (1997) Road transects as a large-scale census method for raptors: the case of the Red Kite Milvus milvus in Spain. Bird Study 44, 155-165.

Viñuela, J. (In press) El Milano Real en España: censo, distribución y conservación. Monografías de la Sociedad Española de Ornitología, No. 5.

Viñuela, J. and Veiga, J. P. (1992) Importance of rabbits in the diet and reproductive success of Black Kites in southwestern Spain. Ornis Scand. 23, 132-138.
Viñuela, J. and Sunyer, C. (1994) Black Kite Milvus migrans. In Birds in Europe: Their Conservation Status, eds G. M. Tucker and M. F. Heath, pp. 148-149. Birdlife Conservation Series no. 3. Birdlife, Cambridge, UK.

Viñuela, J., Villafuerte, R. and de le Court, C. (1994) Nesting dispersion of a Black Kite population in relation to location of rabbits warrens. Can. J. Zool. 72, 1680-1683.

Voisin, J. F. (1994) Milan Royal. In Nouvel atlas des oiseaux nicheurs de France, 1985-1989, ed. D. Yeatman-Berthelot and G. Jarry, pp. 164-165. Societé Ornitologique de France, Paris. 